\title{
How DIRS is refining concepts
}

Like the elaboration of good wine, which is dependent on excellent materials, well-honed techniques, and the passage of time, the evolution of our understanding of diseases and syndromes is dependent on similar features. The recognition of many neuroimmunologic diseases associated with autoantibodies is relatively recent. With time and experience (e.g., more patients and controls), concepts about disease mechanisms or even the syndromes associated with some autoantibodies are being refined or manifest the need for an extensive redefinition. In the current issue of $N 2$, we have some articles on this theme.

The concept that in any autoimmune encephalitis the associated immune response needs to be orchestrated within the CNS may seem obvious, but the view that the CNS has no role other than to passively have the effects of systemic autoantibodies is still frequently encountered. Among all the autoimmune encephalitides, anti-LGI1 is the one most frequently associated with this view. This is seemingly supported by the limited or infrequent presence of inflammatory changes in patients' CSF and the uncommon presence of intrathecal synthesis of antibodies. In this issue, Lehmann-Horn et al. ${ }^{1}$ used paired CSF and peripheral blood (PB) mononuclear cells from 6 patients with anti-LGI1 encephalitis and 2 patients with other neurologic diseases and applied deep B-cell immune repertoire sequencing (DIRS) on immunoglobulin heavy chain transcripts from CSF B cells and sorted PB B cells. The findings showed a restricted CSF repertoire with frequent extensive clusters of clonally related $\mathrm{B}$ cells connected to mature PB B cells. These clusters displayed intensive mutational activity of CSF B cells, suggesting an independent CNSbased antigen-driven response in patients with this disease. Thus, the findings suggest a more complex mechanism than that suggested by the simplistic view of "passive antibody transfer across the $\mathrm{BBB}$ and subsequent binding to the target." The study does not address the antigen specificity of the intrathecal B-cell response; therefore, it remains to be determined whether the expanded CSF clones are directed against LGI-specific epitopes. Another question to address is the lack of CSF LGI1 antibodies in 2 patients despite intense intrathecal somatic hypermutation events. The authors raise the interesting questions of whether DIRS provides a more sensitive measure of B-cell activity than measuring CSF antibodies titers and whether abrogating these cell responses could attenuate disease activity, prevent relapses, and improve long-term outcomes. These interesting findings and several "food for thought questions" await future studies that may have important implications for the treatment of this disease.

In another study, Wickel et al. ${ }^{2}$ describe 2 patients with autoimmune steroid-responsive meningoencephalomyelitis with linear perivascular enhancement in brain MRI. One of the patients had glial fibrillary acidic protein (GFAP) antibodies, and the other was antibody negative, but both cases responded to immunotherapy. The authors argue that the clinical and radiologic picture of these patients are similar to the disorder coined as anti-GFAP astrocytopathy, raising the question of whether these antibodies are disease specific. The authors suggest that the indicated clinical-radiologic syndrome may result from diverse immunologic disorders and that the presence of GFAP is not obligatory. Moreover, they also indicate that it is unclear whether the presence of GFAP antibodies in some patients is just an immunologic 
accompaniment or whether these patients represent a particular subgroup with a specific pathophysiology targeting the astrocyte. Two facts to add to these comments are the detection of GFAP antibodies in patients without the indicated syndrome (meningoencephalitis and radial perivascular enhancement $)^{3}$ and the coexistence of GFAP antibodies with other more relevant antibodies (such as NMDA receptor [NMDAR] or aquaporin 4 [AQP4]) and their corresponding trigger (e.g., ovarian teratoma in anti-NMDAR). ${ }^{4,5}$ In these cases, the resulting syndromes are usually driven by the other antibodies (NMDAR and AQP4) instead of the GFAP immune response. ${ }^{3,4}$ In a study of 42 patients with anti-NMDAR encephalitis and concurrent antibodies, 17 had antibodies against myelin oligodendrocyte (MOG) protein, 10 against GFAP, 3 against AQP4, 6 against the AMPA receptor, 5 against the GABAa receptor, and 1 against the GABAb receptor. In addition to symptoms related to the NMDAR antibodies, most patients had clinical or MRI features typically related to the concurrent antibodies, except those with GFAP antibodies: none of the 10 patients with these antibodies developed clinical or radiologic features of GFAP astrocytopathy, and they only had features of anti-NMDAR encephalitis. ${ }^{6}$ As suggested by Wickel et al. and other investigators, ${ }^{2,3}$ it is time to clarify the disease specificity and clinical significance of GFAP antibodies.

In another study, Möhn et al. $^{7}$ examined the changes in immunoglobulin production that occur in the serum and CSF of patients after treatment with alemtuzumab. This humanized monoclonal antibody binds to CD52, which is highly expressed on the surface of $\mathrm{T}$ and $\mathrm{B}$ cells and at lower levels on the surface of monocytes and macrophages. Studies on repopulation dynamics indicate that $\mathrm{B}$ lymphocyte numbers return to baseline levels much earlier than $\mathrm{T}$ lymphocyte numbers and that some of the adverse effects of the drug, such as autoimmune disorders, likely result from these different dynamics of recovery according to cell subtype (e.g., faster repopulation of B cells in the absence of effective $\mathrm{T}$-cell regulation). In the current study, based on 38 patients, the authors found reduced concentrations of all immunoglobulin classes assessed (IgG, IgM, and $\operatorname{IgA}$ ) in serum and CSF at 12 and 24 months after 2 courses of alemtuzumab. Patients who required a third course of treatment developed further decrease in IgG levels compared with matched patients treated with just 2 courses. Reduced IgG concentrations were associated with an increase in pneumonia, otitis, and sinusitis, suggesting that serum IgG levels should be monitored, particularly in patients receiving more than 2 courses of alemtuzumab. Decreased intrathecal IgG production was also noted in CSF, suggesting effective suppression of the autoimmune process within the CNS. Based on the current findings, the authors suggest that patients be considered for pretreatment pneumococci vaccination. Limitations of the study include the retrospective analysis of data and limited number of patients treated with a third course of alemtuzumab, indicating that the current findings should be verified in future investigations.
In another study, Cobo-Calvo et al. ${ }^{8}$ examined 685 consecutive patients with MS for MOG antibodies. Patients were aged 18 years or older, and all had a definite diagnosis of MS according to $2010 \mathrm{McD}$ onald criteria. Serum samples were tested with a live cell-based assay, and positive cases were reassessed in another laboratory with a second assay using the same plasmid and different secondary antibody. Overall, the median age of the patients at disease onset was 28 years, and the median disease duration at serum sampling was 11.5 years. Only 2 patients $(0.03 \%)$ had MOG antibodies, consistent with the antibody specificity reported in previous studies, ${ }^{9,10}$ although the current study included different subtypes of MS. Besides noting the high specificity of the methods used, the authors conclude that in clinical practice, patients fulfilling the 2010 McDonald criteria of MS (with typical features) do not need MOG antibody testing. As limitations of the study, the authors indicate the cross-sectional design (potentially missing cases that could have had detectable antibodies at different stages of the disease) and the use of steroids and long-term treatments that could have altered the antibody levels.

In addition to these studies, the March issue of N2 contains a position paper on the clinical approach to the diagnosis of autoimmune encephalitis in pediatric patients by Cellucci et al. and other interesting articles that I hope will catch your attention.

\section{Study funding}

No targeted funding reported.

\section{Disclosure}

J. Dalmau holds patents for the use of Ma2, NMDAR, GABABR, GABAAR, DPPX, and IgLON5 as autoantibody tests and receives royalties from the use of these tests. He is Editor of Neurology $y^{\circledast}$ Neuroimmunology \& Neuroinflammation. Go to Neurology.org/NN for full disclosures.

\section{References}

1. Lehmann-Horn K, Irani SR, Wang S, et al. Intrathecal B-cell activation in LGI1 antibody encephalitis. Neurol Neuroimmunol Neuroinflamm 2019;7:e669. doi: 10.1212/NXI.0000000000000669.

2. Wickel J, Chung H-Y, Kirchof K, et al. Encephalitis with radial perivascular emphasis: Not necessarily associated with GFAP antibodies. Neurol Neuroimmunol Neuroinflamm 2019;7:e670. doi: 10.1212/NXI.0000000000000670.

3. Shan F, Long Y, Qiu W. Autoimmune glial fibrillary acidic protein astrocytopathy: a review of the literature. Front Immunol 2018;9:2802.

4. Martin AL, Jolliffe E, Hertweck SP. Ovarian teratoma associated with coexisting antiN-Methyl-D-Aspartate receptor and glial fibrillary acidic protein autoimmune meningoencephalitis in an adolescent girl: a case report. J Pediatr Adolesc Gynecol 2018, 31:321-324.

5. Dubey D, Hinson SR, Jolliffe EA, et al. Autoimmune GFAP astrocytopathy: prospective evaluation of 90 patients in 1 year. J Neuroimmunol 2018;321:157-163.

6. Martinez-Hernandez E, Guasp M, Garcia-Serra A, et al. Clinical significance of antiNMDAR concurrent with glial or neuronal Ssurface antibodies. Neurology (in press).

7. Möhn N, Pfeuffer S, Ruck T, et al. Alemtuzumab therapy changes immunoglobulin levels in peripheral blood and CSF. Neurol Neuroimmunol Neuroinflamm 2019;7: e654. doi: 10.1212/NXI.0000000000000654.

8. Cobo-Calvo A, d'Indy H, Ruiz A, et al. Frequency of myelin oligodendrocyte glycoprotein antibody in multiple sclerosis: A multicenter cross-sectional study. Neurol Neuroimmunol Neuroinflamm 2019;7:e649. doi: 10.1212/NXI.0000000000000649.

9. Waters PJ, Komorowski L, Woodhall M, et al. A multicenter comparison of MOG-IgG cell-based assays. Neurology 2019;92:e1250-e1255.

10. Jarius S, Ruprecht K, Stellmann JP, et al. MOG-IgG in primary and secondary chronic progressive multiple sclerosis: a multicenter study of 200 patients and review of the literature. J Neuroinflammation 2018;15:88. 


\title{
Neurology \\ Neuroimmunology \& Neuroinflammation
}

\author{
How DIRS is refining concepts \\ Josep Dalmau \\ Neurol Neuroimmunol Neuroinflamm 2020;7; \\ DOI 10.1212/NXI.0000000000000677
}

This information is current as of February 7, 2020

Updated Information \&

Services

References

Permissions \& Licensing

Reprints including high resolution figures, can be found at:

http://nn.neurology.org/content/7/2/e677.full.html

This article cites 9 articles, 2 of which you can access for free at: http://nn.neurology.org/content/7/2/e677.full.html\#\#ref-list-1

Information about reproducing this article in parts (figures,tables) or in its entirety can be found online at:

http://nn.neurology.org/misc/about.xhtml\#permissions

Information about ordering reprints can be found online: http://nn.neurology.org/misc/addir.xhtml\#reprintsus

Neurol Neuroimmunol Neuroinflamm is an official journal of the American Academy of Neurology.

Published since April 2014, it is an open-access, online-only, continuous publication journal. Copyright

Copyright (C) 2020 The Author(s). Published by Wolters Kluwer Health, Inc. on behalf of the American

Academy of Neurology.. All rights reserved. Online ISSN: 2332-7812.

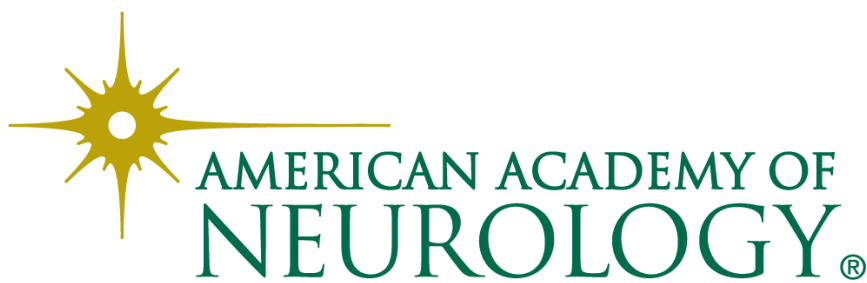

